\title{
COMPARISON OF CRYO TREATMENT EFFECT ON MACHINING CHARACTERISTICS OF TITANIUM IN ELECTRIC DISCHARGE MACHINING
}

\author{
Rupinder Singh and Bhupinder Singh \\ Department of Production Engineering \\ Guru Nanak Dev Engineering College, Ludhiana, 141 006, India \\ Phone: +91-9872257575, Fax: +91-1612502700 \\ E-mail: rupindersingh78@yahoo.com
}

\begin{abstract}
Earlier studies on cryogenic treatment highlighted that certain metals, after being cryogenically treated, show a significant increase in tool life when used in manufacturing, cutting and shaping processes. The present work deals with experimental investigation of the role of cryogenic treatment on the machining characteristics of titanium in electric discharge machining (EDM). EDM is a potential process to commercially machine tough materials like titanium alloys, due to the properties of non-mechanical contact between the tool and workpiece and the capability to machine intricate shapes. In this research work an effort has been made to compare the machining characteristics of titanium with EDM, before and after cryogenic treatment of the tool and workpiece using a Taguchi design approach. The output parameters for study are material removal rate (MRR), tool wear rate (TWR), surface roughness (SR) and dimensional accuracy $(\Delta \mathrm{d})$. The results of the study suggest that with cryogenic treatment MRR, TWR, SR and $\Delta d$ show an improvement of $60.39 \%$, $58.77 \%, 7.99 \%$ and $80.00 \%$ respectively.
\end{abstract}

Keywords: electric discharge machining; material removal rate; tool wear rate; surface roughness; dimensional accuracy.

\section{INTRODUCTION}

There are a number of treatment processes used for different metals which cause them to behave differently under different conditions (Dhar et al., 2002). Empirical studies have demonstrated that the life of cutting tools can be increased by cryogenic treatment (Gill et al., 2010). Cryogenic treatment may be oversimplified into a process of chilling a part down to relatively near absolute zero and maintaining that condition until the material has cold-soaked (Gill et al., 2008). The temperature is then allowed to rise until ambient equilibrium is reached (Molinari et al., 2001). The part may then be subjected to a normal tempering reheat, although this step is not always included in the process. The complexity of the process involves determining and achieving the proper duration for the cooling, soaking and warming cycles (Kamody, 1993). Figure 1 shows a schematic of cryogenic equipment.

EDM is a controlled metal removal process that is used to remove metal by means of electric spark erosion (Sarkar et al., 2006). In this process an electric spark is used as the cutting tool to cut (erode) the workpiece to produce the finished part to the desired shape (Liao et al., 1997). The metal removal process is performed by applying a 
pulsating (ON/OFF) electrical charge of high-frequency current through the electrode to the workpiece. This removes (erodes) very tiny pieces of metal from the workpiece at a controlled rate (Ramakrishnan and Karunamoorthy, 2006). Figure 2 shows a schematic of the EDM process.

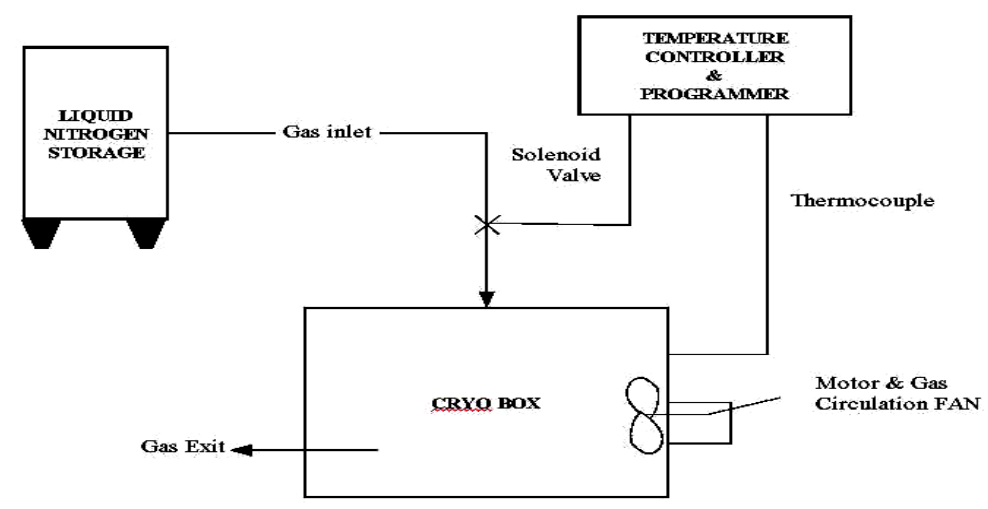

Figure 1. Schematic of cryogenic equipment (Singh \& Singh, 2010)

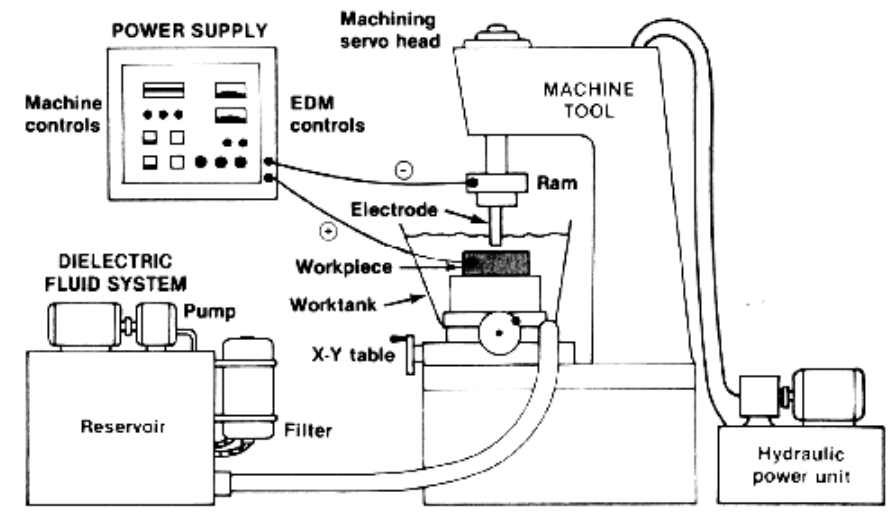

Figure 2. Schematic of EDM process (Singh, 2009)

Titanium (Ti) and its alloys exhibit excellent corrosion resistance and have high strength to weight ratio, which makes them ideal for use primarily in two areas of application: corrosion-resistant service and specific strength for efficient structures. Normally, low strength, unalloyed, commercially pure (CP) Ti is used in the fabrication of tanks, heat exchangers and reactor vessels for chemical processing and power generation plants. High strength $\mathrm{Ti}$ alloys are used in high performance applications such as aerospace (Sarkar et al., 2006). The conventional method in machining of $\mathrm{Ti}$ alloys is not suitable (Singh, 2009). Research on machining of pure Ti using conventional machines highlights chipping, stresses, cutting tool wear and thermal problems during machining which are caused by mechanical energy. Instead of conventional machining, the EDM process is a potential machining method to eliminate such problems (Puri and Bhattacharya, 2003). This is because there is no mechanical contact between the tool and workpiece in the EDM system (Saha, 2008). Furthermore, machining with EDM is burr-less, highly accurate and has the capability to produce intricate cavities in one operation. However, not much work has been reported hitherto on EDM of pure Ti (Singh, 2009). 
The objective of the present work is to compare the machining characteristics of $\mathrm{Ti}$ with EDM, before and after cryogenic treatment of the tool and workpiece using the Taguchi design approach. In the present study cryo-treatment was done at $-80^{\circ} \mathrm{C}$ (Reitz and Pendray, 2001; Molinari et al., 2002). Figures 3 and 4 show cryogenic and tempering cycles for the present study. The output parameters for study are material removal rate (MRR), tool wear rate (TWR), surface roughness (SR) and dimensional $\operatorname{accuracy}(\Delta \mathrm{d})$.

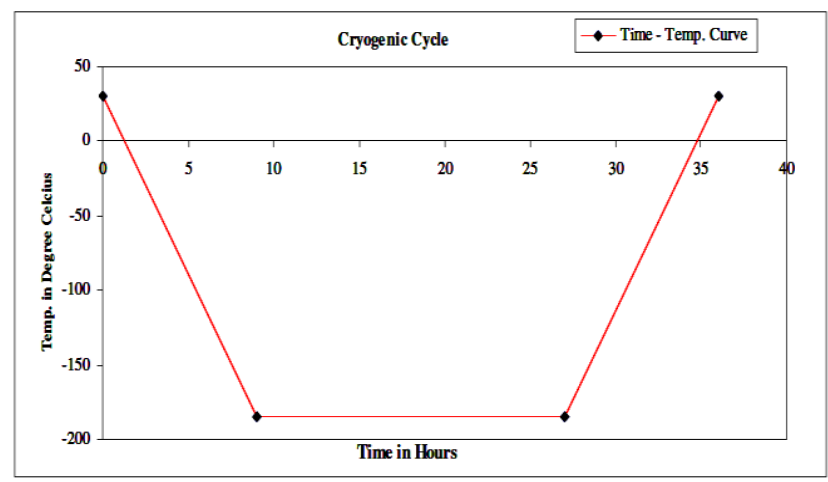

Figure 3. Cryogenic cycle

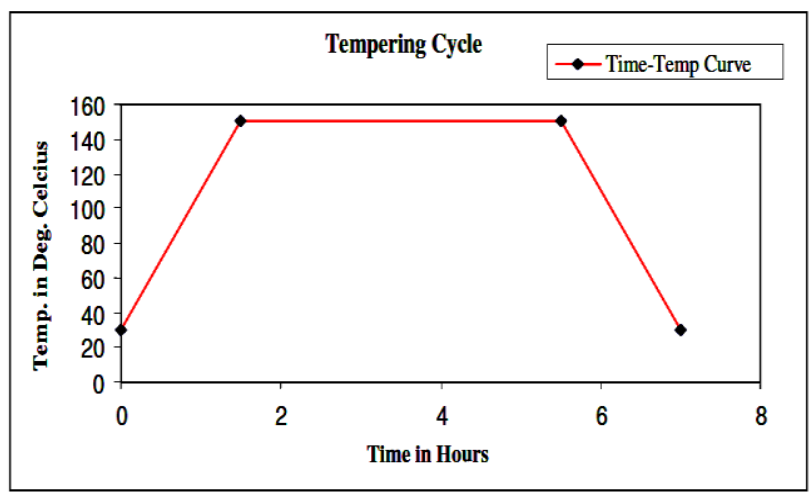

Figure 4. Tempering cycle

\section{EXPERIMENTAL DETAILS}

The material selected for the study was CP Ti (Titan 15) ASTM Gr.2 as the workpiece and $\mathrm{Ti}$, copper $(\mathrm{Cu})$ and copper chromium $(\mathrm{CuCr})$ as electrode/tool materials. Table 1 shows the chemical composition of the workpiece. The workpiece samples were cut into $20 \mathrm{~mm} \times 12 \mathrm{~mm} \times 12 \mathrm{~mm}$ and electrodes were of $6 \mathrm{~mm}$ diameter and $100 \mathrm{~mm}$ length for the experimentation. Table 2 shows a list of input parameters for the present study. The experimentation was conducted on a CNC EDM machine. Table 3 summarizes the results of pilot experiments with different combinations of electrode, workpiece and current.

Table 1. Chemical analysis (\%) TITAN 15 (UTS $491 \mathrm{MPa)}$

\begin{tabular}{llllll}
\hline $\mathrm{C}$ & $\mathrm{H}$ & $\mathrm{N}$ & $\mathrm{O}$ & $\mathrm{Fe}$ & $\mathrm{Ti}$ \\
\hline 0.006 & 0.0007 & 0.014 & 0.140 & 0.05 & Balance \\
\hline
\end{tabular}


Table 2. Input parameters

\begin{tabular}{|c|c|c|}
\hline $\begin{array}{c}\text { Work material } \\
\text { CP Ti }\end{array}$ & Non-cryo treated/plain & Cryogenically treated \\
\hline Tool Materials & $\begin{array}{l}\text { CuCr (Non-cryo treated) } \\
\text { Copper (Non-cryo treated) } \\
\text { Ti (Non-cryo treated) }\end{array}$ & $\begin{array}{l}\text { CuCr (Cryogenically treated) } \\
\mathrm{Cu} \text { (Cryogenically treated) } \\
\mathrm{Ti} \text { (Cryogenically treated) }\end{array}$ \\
\hline Current Ampere & 2 & 6 \\
\hline
\end{tabular}

Table 3. Experimental Observations

\begin{tabular}{|c|c|c|c|c|c|c|c|c|c|c|c|c|c|}
\hline & & & & & put para & ters & & & & & Output Para & neters & \\
\hline & & Work & & & Initia & $\begin{array}{l}\text { weight } \\
\text { n) }\end{array}$ & Final & & Time & TWR & MRR & SR & $\Delta \mathrm{d}$ \\
\hline & trode & Piece & & & Tool & $\begin{array}{l}\text { Work } \\
\text { piece }\end{array}$ & Tool & $\begin{array}{l}\text { Work } \\
\text { piece }\end{array}$ & (min) & (gm/min) & (gm/min) & $(\mu \mathrm{m})$ & $(\mathrm{mm})$ \\
\hline & & & A1 & 2 & 11.697 & 16.789 & 10.516 & 15.614 & 108 & 0.0109352 & 0.0108796 & 0.595 & 0.06 \\
\hline & $\dot{F}$ & & $\mathrm{~A} 2$ & 4 & 10.516 & 15.614 & 9.387 & 14.476 & 99 & 0.011404 & 0.0114949 & 0.609 & 0.07 \\
\hline$\stackrel{\Xi}{=}$ & & & A3 & 6 & 9.387 & 14.476 & 8.338 & 13.325 & 92 & 0.0114022 & 0.0125109 & 0.628 & 0.07 \\
\hline$\stackrel{\Xi}{\Xi}$ & & & $\mathrm{A} 1$ & 2 & 23.69 & 14.578 & 22.173 & 13.416 & 82 & 0.0185 & 0.0141707 & 0.603 & 0.06 \\
\hline$\overline{\bar{乛}}$ & $\exists$ & & $\mathrm{A} 2$ & 4 & 22.173 & 13.416 & 20.603 & 12.296 & 73 & 0.0215068 & 0.0153425 & 0.613 & 0.06 \\
\hline $\begin{array}{l}\overline{\bar{D}} \\
0 \\
0\end{array}$ & & & A3 & 6 & 20.603 & 12.296 & 19.396 & 11.139 & 62 & 0.0194677 & 0.0186613 & 0.632 & 0.07 \\
\hline & & & $\mathrm{A} 1$ & 2 & 22.896 & 16.409 & 21.316 & 15.287 & 86 & 0.0183721 & 0.0130465 & 0.599 & 0.06 \\
\hline & $\vec{\Xi}$ & ت & A2 & 4 & 21.316 & 15.287 & 19.667 & 14.109 & 76 & 0.0216974 & 0.0155 & 0.612 & 0.07 \\
\hline & & 馬 & $\mathrm{A} 3$ & 6 & 19.667 & 14.109 & 18.464 & 12.921 & 65 & 0.0185077 & 0.0182769 & 0.631 & 0.07 \\
\hline & & $\sum_{\substack{0 \\
1}}$ & $\mathrm{~A} 1$ & 2 & 14.89 & 20.513 & 13.671 & 19.287 & 117 & 0.0104188 & 0.0104786 & 0.591 & 0.1 \\
\hline & $\dot{F}$ & है & A2 & 4 & 13.671 & 19.287 & 12.443 & 17.896 & 109 & 0.0112661 & 0.0127615 & 0.606 & 0.1 \\
\hline & & & $\mathrm{A} 3$ & 6 & 12.443 & 17.896 & 11.414 & 16.589 & 98 & 0.0105 & 0.0133367 & 0.622 & 0.09 \\
\hline 苞 & & & A1 & 2 & 28.143 & 17.918 & 26.491 & 16.176 & 83 & 0.0199036 & 0.020988 & 0.597 & 0.09 \\
\hline ํㅜㅇ & U & & $\mathrm{A} 2$ & 4 & 26.491 & 16.176 & 24.729 & 14.319 & 77 & 0.0228831 & 0.0241169 & 0.612 & 0.1 \\
\hline ĩ & & & A3 & 6 & 24.729 & 14.319 & 23.287 & 12.573 & 66 & 0.0218485 & 0.0264545 & 0.629 & 0.09 \\
\hline & & & $\mathrm{A} 1$ & 2 & 27.674 & 19.981 & 26.149 & 18.546 & 88 & 0.0173295 & 0.0163068 & 0.594 & 0.1 \\
\hline & $\bar{Z}$ & & A2 & 4 & 26.149 & 18.546 & 24.604 & 16.906 & 79 & 0.019557 & 0.0207595 & 0.609 & 0.09 \\
\hline & & & A3 & 6 & 24.604 & 16.906 & 23.317 & 15.409 & 68 & 0.0189265 & 0.0220147 & 0.627 & 0.09 \\
\hline & & & $\mathrm{A} 1$ & 2 & 14.97 & 20.015 & 13.819 & 18.685 & 122 & 0.0094344 & 0.0109016 & 0.587 & 0.02 \\
\hline & $\dot{F}$ & & A2 & 4 & 13.819 & 18.685 & 12.695 & 17.165 & 109 & 0.0103119 & 0.013945 & 0.599 & 0.04 \\
\hline$\vec{d}$ & & $\vec{Z}$ & $\mathrm{~A} 3$ & 6 & 12.695 & 17.165 & 11.697 & 15.623 & 102 & 0.0097843 & 0.0151176 & 0.618 & 0.04 \\
\hline 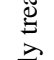 & & $\stackrel{\Xi}{\Xi}$ & A1 & 2 & 28.14 & 17.876 & 26.473 & 16.413 & 89 & 0.0187303 & 0.0164382 & 0.593 & 0.03 \\
\hline 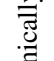 & $\tilde{J}$ & 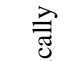 & $\mathrm{A} 2$ & 4 & 26.473 & 16.413 & 24.816 & 15.109 & 76 & 0.0218026 & 0.0171579 & 0.605 & 0.03 \\
\hline 㷰 & & 苛 & A3 & 6 & 24.816 & 15.109 & 23.69 & 13.853 & 67 & 0.016806 & 0.0187463 & 0.628 & 0.04 \\
\hline Uे & & 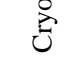 & $\mathrm{A} 1$ & 2 & 26.945 & 17.503 & 25.597 & 16.024 & 93 & 0.0144946 & 0.0159032 & 0.591 & 0.03 \\
\hline & $\Xi$ & & $\mathrm{A} 2$ & 4 & 25.597 & 16.024 & 24.076 & 14.637 & 81 & 0.0187778 & 0.0171235 & 0.603 & 0.04 \\
\hline & & & A3 & 6 & 24.076 & 14.637 & 22.896 & 13.296 & 73 & 0.0161644 & 0.0183699 & 0.624 & 0.04 \\
\hline
\end{tabular}


Table 3. (continued)

\begin{tabular}{|c|c|c|c|c|c|c|c|c|c|c|c|c|c|}
\hline \multicolumn{10}{|c|}{ Input parameters } & \multicolumn{4}{|c|}{ Output Parameters } \\
\hline \multirow{2}{*}{\multicolumn{2}{|c|}{$\begin{array}{c}\text { Tool/ } \\
\text { Electrode }\end{array}$}} & \multirow{2}{*}{$\begin{array}{l}\text { Work } \\
\text { Piece }\end{array}$} & \multirow{2}{*}{\multicolumn{2}{|c|}{$\begin{array}{l}\text { Current } \\
\text { (Amp) }\end{array}$}} & \multicolumn{2}{|c|}{ Initial weight $(\mathrm{gm})$} & \multicolumn{2}{|c|}{$\begin{array}{l}\text { Final weight } \\
\quad(\mathrm{gm})\end{array}$} & \multirow{2}{*}{$\begin{array}{c}\text { Time } \\
\text { Taken } \\
\text { (min) }\end{array}$} & \multirow{2}{*}{$\begin{array}{c}\text { TWR } \\
(\mathrm{gm} / \mathrm{min})\end{array}$} & \multirow{2}{*}{$\begin{array}{c}\text { MRR } \\
(\mathrm{gm} / \mathrm{min})\end{array}$} & \multirow{2}{*}{$\begin{array}{c}\text { SR } \\
(\mu \mathrm{m})\end{array}$} & \multirow{2}{*}{$\begin{array}{r}\Delta \mathrm{d} \\
(\mathrm{mm}\end{array}$} \\
\hline & & & & & Tool & $\begin{array}{l}\text { Work } \\
\text { piece }\end{array}$ & Tool & $\begin{array}{l}\text { Work } \\
\text { piece }\end{array}$ & & & & & \\
\hline \multirow{9}{*}{ 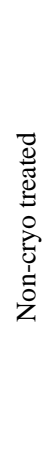 } & \multirow{3}{*}{ 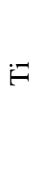 } & & $\mathrm{A} 1$ & 2 & 11.414 & 16.923 & 10.293 & 15.784 & 104 & 0.0107788 & 0.0109519 & 0.601 & 0.05 \\
\hline & & & A2 & 4 & 10.293 & 15.784 & 9.046 & 14.629 & 96 & 0.0129896 & 0.0120313 & 0.617 & 0.05 \\
\hline & & & $\mathrm{A} 3$ & 6 & 9.046 & 14.629 & 8.103 & 13.486 & 77 & 0.0122468 & 0.0148442 & 0.633 & 0.05 \\
\hline & \multirow{3}{*}{$\tilde{J}$} & & A1 & 2 & 22.719 & 14.453 & 21.343 & 13.311 & 77 & 0.0178701 & 0.0148312 & 0.607 & 0.04 \\
\hline & & & A2 & 4 & 21.343 & 13.311 & 19.856 & 12.19 & 71 & 0.0209437 & 0.0157887 & 0.623 & 0.05 \\
\hline & & & A3 & 6 & 19.856 & 12.19 & 18.493 & 11.035 & 66 & 0.0206515 & 0.0175 & 0.638 & 0.05 \\
\hline & \multirow{3}{*}{$\ddot{U}$} & & $\mathrm{~A} 1$ & 2 & 23.317 & 13.96 & 21.783 & 12.809 & 81 & 0.0189383 & 0.0142099 & 0.605 & 0.05 \\
\hline & & & A2 & 4 & 21.783 & 12.809 & 20.109 & 11.651 & 72 & 0.02325 & 0.0160833 & 0.618 & 0.06 \\
\hline & & & A3 & 6 & 20.109 & 11.651 & 18.676 & 10.463 & 64 & 0.0223906 & 0.0185625 & 0.635 & 0.06 \\
\hline
\end{tabular}

MRR is defined as the difference between the initial weight of the workpiece (before machining) and the final weight of the workpiece (after machining with EDM). TWR is defined as the difference between the initial weight of the tool (before machining) and the final weight of the tool (after machining with EDM).

Mathematically MRR $=\left(W_{1}-W_{2}\right) / t$

where $W_{1}$ is the initial weight of work-piece in gm (before machining)

$W_{2}$ is the final weight of work-piece in gm (after machining)

$t$ is the machining time in minutes for ' $01 \mathrm{~mm}$ ' fixed depth of cut in workpiece, measured with a stopwatch.

Mathematically TWR $=\left(\mathrm{V}_{1}-\mathrm{V}_{2}\right) / \mathrm{t}$

where $V_{1}$ is the initial weight of the tool in gm (before machining)

$V_{2}$ is the final weight of the tool in gm (after machining)

$t$ is machining time in minutes for ' $01 \mathrm{~mm}$ ' fixed depth of cut in workpiece measured with a stopwatch.

SR was measured as ' $R_{a}$ value' expressed in microns by using a surface roughness measuring instrument (Talysurf).

\section{RESULTS AND DISCUSSION}

Based upon pilot experimental data (Table 3), a Taguchi L9 orthogonal array was used to optimize MRR, TWR, SR and $\Delta \mathrm{d}$. Final experimentation was conducted in four sets. In the first set, a cryogenically treated electrode and cryogenically treated workpiece were machined using EDM. In the second setup, a non-cryo treated electrode and non-cryo treated workpiece were selected. In third setup, a non-cryo treated workpiece was machined with a cryogenically treated electrode. In the final setup, a non-cryo treated electrode and cryogenically treated workpiece combination was selected. Table 4 shows the factors description for the cryogenically treated/non-treated electrode and workpiece. 
With the help of MINITAB 15 software, the ANOVA was performed to attain the plots and conditions where MRR, TWR SR and $\Delta \mathrm{d}$ have optimized value. The results are valid for $95 \%$ accuracy. The ANOVA result shows the value of degree of freedom (DOF), sum of squares (Seq. SS), adjustable mean squares (Adj. MS) and value of F and $\mathrm{P}$ test. Figure 5 shows machining parameters versus current for the cryogenically treated electrode and cryogenically treated workpiece and Figure 6 shows the main effects plots by ANOVA analysis from the average value for (a) $\Delta$ d (b) SR (c) MRR (d) TWR. The following ANOVA results were obtained for the cryogenically treated electrode and cryogenically treated workpiece:

Workpiece: Cryogenic Ti

General Linear Model: TWR, MRR, SR, $\Delta d$ versus Current, Tool

Factor Type Levels Values

Current fixed $32,4,6$

Tool fixed 3 Cryogenic Ti, Cryogenic $\mathrm{Cu}$,

Cryogenic $\mathrm{CuCr}$

Analysis of Variance for TWR, using Adjusted SS for Tests

$\begin{array}{lllccc}\text { Source } & \text { DF } & \text { Seq SS } & \text { Adj MS } & \text { F } & \text { P } \\ \text { Current } & 2 & 0.0000149 & 0.0000074 & 3.96 & 0.113 \\ \text { Tool } & 2 & 0.0001369 & 0.0000684 & 36.39 & 0.003 \\ \text { Error } & 4 & 0.0000075 & 0.0000019 & & \\ \text { Total } \quad 8 & 0.0001593 & & & \\ \text { S }=0.00137150 & & & & \end{array}$

Analysis of Variance for MRR, using Adjusted SS for Tests

$\begin{array}{lllccc}\text { Source } & \text { DF } & \text { Seq SS } & \text { Adj MS } & \text { F } & \text { P } \\ \text { Current } & 2 & 0.0000135 & 0.0000068 & 15.22 & 0.013 \\ \text { Tool } & 2 & 0.0000316 & 0.0000158 & 35.61 & 0.003 \\ \text { Error } & 4 & 0.0000018 & 0.0000004 & & \\ \text { Total } & 8 & 0.0000469 & & & \\ \text { S }=0.000666547 & & & & \end{array}$

Analysis of Variance for SR, using Adjusted SS for Tests

$\begin{array}{llllll}\text { Source } & \text { DF } & \text { Seq SS } & \text { Adj MS } & \text { F } & \text { P } \\ \text { Current } & 2 & 0.0016740 & 0.0008370 & 627.75 & 0.000 \\ \text { Tool } & 2 & 0.0000827 & 0.0000413 & 31.00 & 0.004 \\ \text { Error } & 4 & 0.0000053 & 0.0000013 & & \\ \text { Total } & 8 & 0.0017620 & & & \\ \text { S }=0.00115470 & & & & \end{array}$

Analysis of Variance for $\Delta d$, using Adjusted SS for Tests

$\begin{array}{lllccc}\text { Source } & \text { DF } & \text { Seq SS } & \text { Adj MS } & \text { F } & \text { P } \\ \text { Current } & 2 & 0.0002889 & 0.0001444 & 5.20 & 0.077 \\ \text { Tool } & 2 & 0.0000222 & 0.0000111 & 0.40 & 0.694 \\ \text { Error } & 4 & 0.0001111 & 0.0000278 & & \\ \text { Total } & 8 & 0.0004222 & & & \\ \text { S }=0.00527046 & & & & \end{array}$


From the above ANOVA analysis and main effects plots it can be summarised that:

1. For the cryogenic Ti workpiece a minimum value of TWR (i.e. 0.00943443 $\mathrm{gm} / \mathrm{min}$ ) was achieved with the cryogenic Ti tool and the current was 2 Amps.

2. For the cryogenic Ti workpiece a maximum value of MRR (i.e. 0.018746269 $\mathrm{gm} / \mathrm{min}$ ) was achieved with the cryogenic $\mathrm{Cu}$ tool and the value of the current was 6 Amps.

3. For the cryogenic Ti workpiece a minimum value of SR (i.e. $0.587 \mu \mathrm{m}$ ) was achieved with the cryogenic Ti tool and the value of the current was 2 Amps.

4. For the cryogenic Ti workpiece a minimum value of $\Delta \mathrm{d}$ (i.e. $0.02 \mathrm{~mm}$ ) was achieved with the cryogenic Ti tool and the value of the current was 2 Amps.

On the same lines, ANOVA analysis for set 2, 3 and 4 was conducted. Based upon ANOVA analysis and main effects plots, the general conditions for optimization were obtained. The overall optimized values of TWR, MRR, SR and $\Delta \mathrm{d}$ are summarized as:

1. The overall optimized value of TWR was achieved with a combination of a cryogenic titanium workpiece, cryogenic titanium tool and 2 Amp current.

2. The overall optimized value of MRR was achieved with a combination of a noncryo treated titanium workpiece, non-cryo treated copper tool and 6 Amp current.

3. The overall optimized value of SR was achieved with a combination of a cryogenic titanium workpiece, cryogenic titanium tool and 2 Amp current.

4. The overall optimized value of $\Delta d$ was achieved with a combination of a cryogenic titanium workpiece, cryogenic titanium tool and 2 Amp current.

Table 4. Factors description for cryogenically treated/non-treated electrode and

\begin{tabular}{|c|c|c|c|c|c|c|c|c|c|c|c|c|}
\hline \multirow{3}{*}{ Factors } & & & & & vO1 & & \multirow{2}{*}{\multicolumn{3}{|c|}{$\begin{array}{c}\text { Level } \\
\text { Description } \\
\text { Setup } 3\end{array}$}} & \multirow{2}{*}{\multicolumn{3}{|c|}{$\begin{array}{c}\text { Level } \\
\text { Description } \\
\text { Setup 4 }\end{array}$}} \\
\hline & \multicolumn{3}{|c|}{$\begin{array}{c}\text { Level } \\
\text { Description } \\
\text { Setup 1 }\end{array}$} & \multicolumn{3}{|c|}{$\begin{array}{c}\text { Level } \\
\text { Description } \\
\text { Setup } 2\end{array}$} & & & & & & \\
\hline & 1 & 2 & 3 & 1 & 2 & 3 & 1 & 2 & 3 & 1 & 2 & 3 \\
\hline 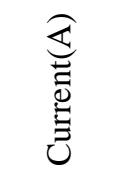 & 2 & 4 & 6 & 2 & 4 & 6 & 2 & 4 & 6 & 2 & 4 & 6 \\
\hline $\overrightarrow{8}$ & 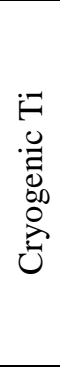 & 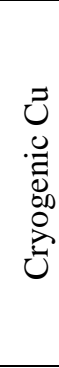 & 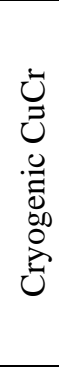 & 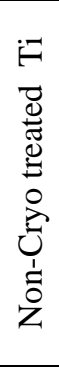 & 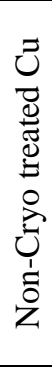 & 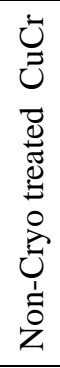 & 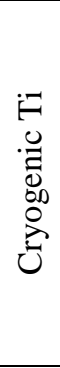 & 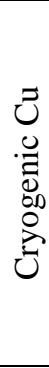 & 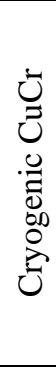 & 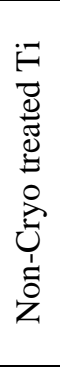 & 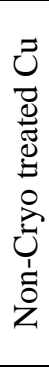 & 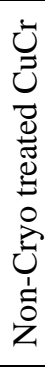 \\
\hline 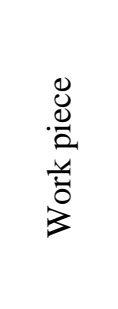 & 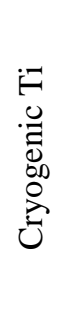 & 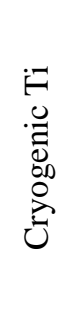 & 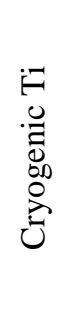 & 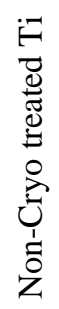 & 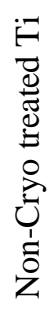 & 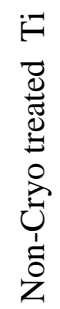 & 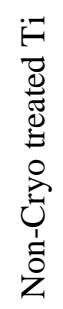 & 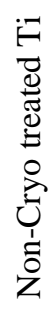 & 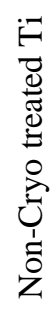 & 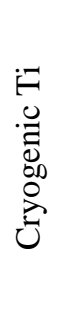 & 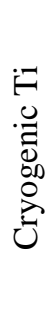 & 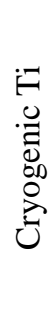 \\
\hline
\end{tabular}




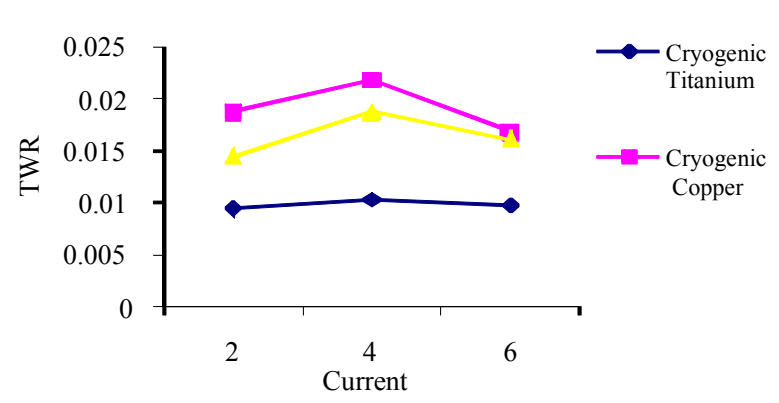

(a)

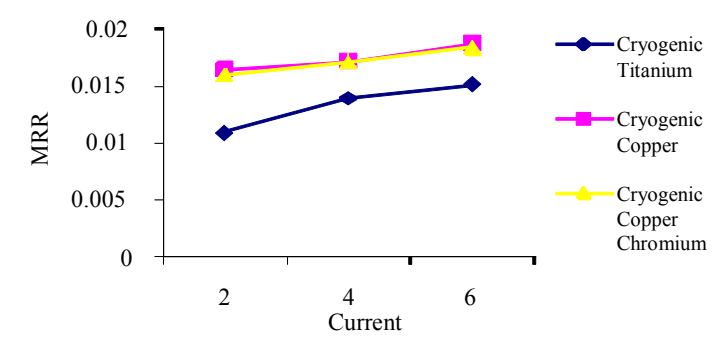

(b)

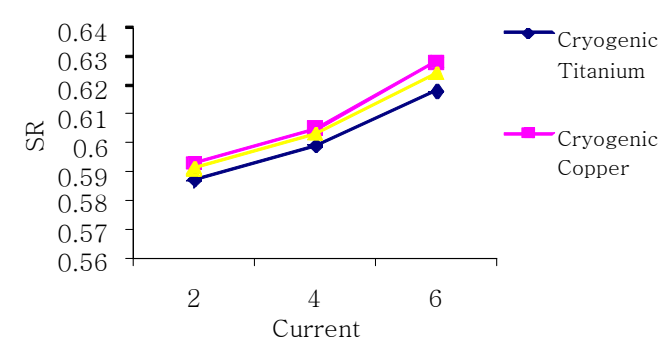

(c)

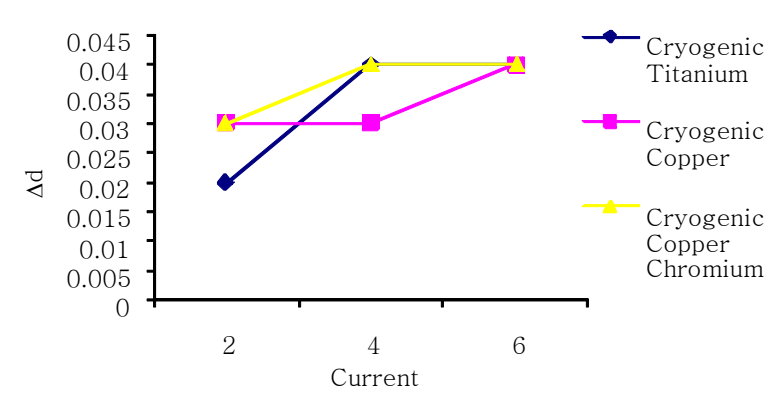

(d)

Figure 5. Machining parameters versus current for cryogenically treated electrode and cryogenically treated workpiece

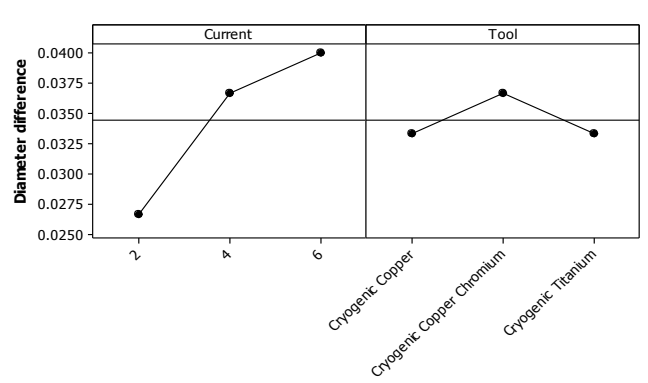

(a)

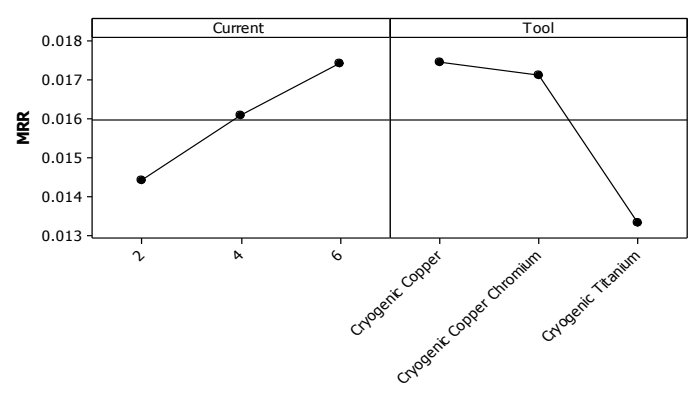

(c)

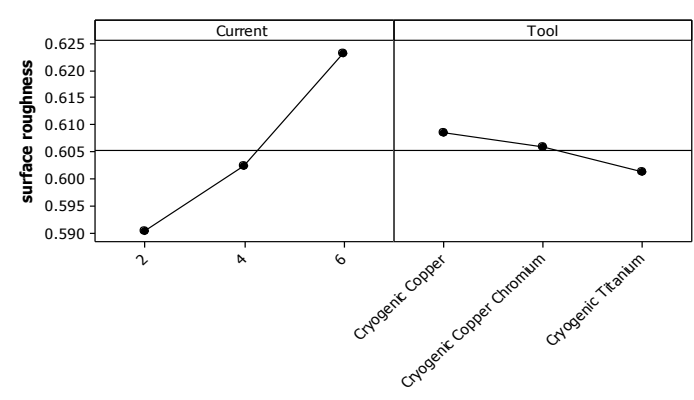

(b)

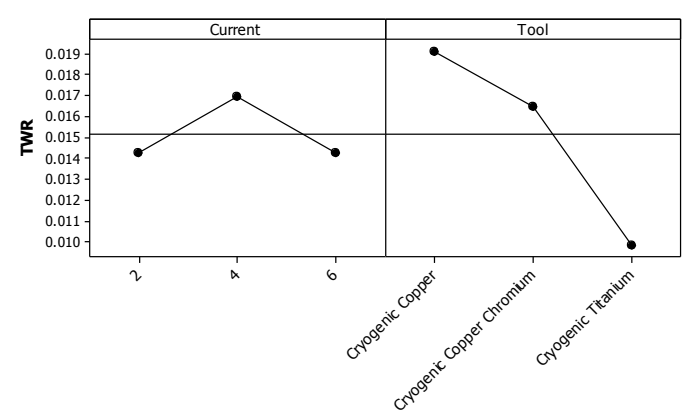

(d)

Figure 6. Main effects Plot by ANOVA analysis from average value for (a) $\Delta$ d(b) SR(c) MRR (d) TWR 


\section{CONCLUSIONS}

The results of the present study show that, with the help of cryogenic treatment, machining parameters like MRR, TWR SR and $\Delta d$ improve significantly when machined on EDM with $\mathrm{CP} \mathrm{Ti}$ as the workpiece. The results are in line with the observations made by other investigators. For checking the adequacy of the model, verification experiments were conducted and it was found that MRR showed an improvement of $60.39 \%$, TWR showed an improvement of $58.77 \%$, SR showed an improvement of $07.99 \%$ and $\Delta \mathrm{d}$ showed an improvement of $80.00 \%$.

\section{ACKNOWLEDGEMENT}

The authors would like to thank Dr. M.S.Saini (Director, GNDEC Ludhiana) for providing laboratory facilities. The authors are also thankful to AICTE, New Delhi for financial support under RPS.

\section{REFERENCES}

Dhar, A.R, Paul, S. and Chhatopadhaya, A.B. 2002. Machining of AISI4140 steel under cryogenic cooling-tool wear, surface roughness \& dimensional deviation. Journal of Material Processing Technology, 123: 483-489.

Gill, S.S., Singh, H., Singh, R. and Singh, J. 2010. Cryoprocessing of cutting tool materials- a review. International Journal of Advanced Manufacturing and Technology, 48: 175-192.

Gill, S.S., Singh, R., Singh, H. and Singh, J. 2008. Wear behaviour of cryogenically treated tungsten carbide inserts under dry and wet turning conditions. International Journal of Machine Tools Manufacturing, 49, 256-260.

Kamody, D.J. (1993) Cryo-treatment. US Patent 5: 259,200.

Liao, Y.S., Chiu, Y.Y. and Yan, M.T. 1997. Study of wire breaking process and monitoring of WEDM. International Journal of Machine Tools and Manufacture, 37(4): 555-567.

Molinari, A., Pellizzari, M., Gialanella, S., Straffelini, G. and Stiasny, K.H. 2001. Effect of deep cryogenic treatment on the mechanical properties of tool steels. Journal of Material Processing Technology, 118: 350-355.

Molinari, A., Pellizzaria, M., Gialanella, S., Staffelini, G. and Stiasny, K.H. 2001. Effect of deep cryogenic treatment on mechanical properties of tool steels. Journal of Materials Processing Technology, 118(1-3): 350-355.

Puri, B.A. and Bhattacharyya, B. 2003. An analysis and optimisation of the geometrical inaccuracy due to wire lag phenomenon in WEDM. International Journal of Machine Tools and Manufacture, 43: 151-159.

Ramakrishnan, R. and Karunamoorthy, L. 2006. Multi response optimization of wire EDM operations using robust design of experiments. International Journal of Advanced Manufacturing Technology, 29: 105-112.

Reitz, W. and Pendray J. 2001. Cryo-processing of materials - A review of current status. Journal of Materials \& Manufacturing Processes, 16(6): 829-840.

Saha, S.K. 2008. Experimental investigation of the dry electric discharge machining (Dry EDM) process. M. Tech Thesis in Department of Mechanical Engineering, IIT Kanpur, pp. 22-35. 
Sarkar, S., Mitra, S. and Bhatacharyya, B. 2006. Parametric optimisation of wire electrical discharge machining of $\gamma$ titanium aluminide alloy through an artificial neural network model. International Journal of Advanced Manufacturing Technology, 27: 501-508.

Singh, B. 2009. Effect of cryogenic treatment for enhancing life of EDM tool while machining pure titanium. M.Tech Thesis, PTU, Jalandhar, India, pp. 13-32.

Singh, K. and Singh, R. 2010. Experimental investigations for tool life enhancement using cryogenic treatment. National Conference on Advancements and Futuristic Trends in Mechanical and Materials Engineering at Punjabi University Guru Kashi Campus, Talwandi Sabo, pp. 53-56.

\section{Nomenclatures}

$\begin{array}{ll}\text { Adj MS } & \text { adjustable mean square } \\ \text { DF } & \text { degree of freedom } \\ \text { MRR } & \text { material removal rate } \\ \text { Seq SS } & \begin{array}{l}\text { sum of squares } \\ \text { SR }\end{array} \\ t & \begin{array}{l}\text { surface roughness } \\ \text { machining time in minutes for '01mm' fixed depth of cut in work- } \\ \text { piece, measured with stopwatch. }\end{array} \\ \text { TWR } & \text { tool wear rate } \\ V_{1} & \text { initial weight of tool in gm (before machining) } \\ V_{2} & \text { final weight of tool in gm (after machining) } \\ W_{1} & \text { initial weight of work-piece in gm (before machining) } \\ W_{2} & \text { final weight of work-piece in gm (after machining) } \\ \Delta d & \text { dimensional accuracy }\end{array}$

\section{Greek symbols}

$\begin{array}{ll}\Delta & \text { Accuracy } \\ \mu & \text { Micron }\end{array}$

